

\section{Daftar Isi (Table of Content) Journal of Government
Civil Society}

\begin{tabular}{|c|c|}
\hline \multirow{3}{*}{$1-30$} & $\begin{array}{l}\text { The Application of Social Movement as a Form of Digital Advocacy: Case of } \\
\text { \#TolakRUUPermusikan }\end{array}$ \\
\hline & Muhammad Ananda Alifiarry ${ }^{1}$, Bevaola Kusumasari ${ }^{1}$ \\
\hline & $\begin{array}{l}\left({ }^{1} \text { Department of Public Policy and Management, Faculty of Social and Political Sciences, }\right. \\
\text { Universitas Gadjah Mada, Indonesia) }\end{array}$ \\
\hline \multirow{3}{*}{$31-50$} & $\begin{array}{l}\text { Urban Resilience Strategy in the Climate Change Governance in Makassar } \\
\text { City, Indonesia }\end{array}$ \\
\hline & $\begin{array}{l}\text { Ihyani Malik }{ }^{1} \text {, Andi Luhur Prianto }{ }^{2} \text {, Abdillah Abdillah², Zaldi Rusnaedy }{ }^{3} \text {, } \\
\text { Andi Annisa Amalia }{ }^{4}\end{array}$ \\
\hline & $\begin{array}{l}\text { (' Department of Public Administration, Universitas Muhammadiyah Makassar, Indonesia) } \\
\text { (' Department of Government Studies, Universitas Muhammadiyah Makassar, Indonesia) } \\
\text { ( }{ }^{3} \text { Department of Government Studies, Universitas Pancasakti Makassar, Indonesia) } \\
\text { ( }{ }^{4} \text { Department of Architecture, Faculty of Engineering, Universitas Muhammadiyah } \\
\text { Makassar, Indonesia) }\end{array}$ \\
\hline \multirow{3}{*}{$51-62$} & $\begin{array}{l}\text { Collaboration Governance in The Development of Natural Based Tourism } \\
\text { Destinations }\end{array}$ \\
\hline & 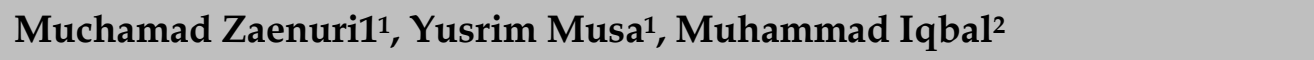 \\
\hline & $\begin{array}{l}\text { (1 Department of Government Affairs and Administration Universitas Muhammadiyah } \\
\text { Yogyakarta, Indonesia) } \\
\text { (2 Department of Political Science National Cheng Kung University, Taiwan, Province of } \\
\text { China) }\end{array}$ \\
\hline \multirow{3}{*}{$63-78$} & $\begin{array}{l}\text { Analysis of Mind Patterns and Work Culture in Government of West } \\
\text { Pasaman District }\end{array}$ \\
\hline & $\begin{array}{l}\text { Sri Andri Yani1 }{ }^{1} \text {, Etika Khairina1, Suswanta1, Mochammad Iqbal } \\
\text { Fadhlurrohman' }\end{array}$ \\
\hline & (1 Governmental Studies, Universitas Muhammadiyah Yogyakarta, Indonesia) \\
\hline \multirow{2}{*}{$79-90$} & $\begin{array}{l}\text { The Influence of Social Media (Instagram) of Bantul's General Election } \\
\text { Commissions on Voters Participation in the } 2019 \text { Elections }\end{array}$ \\
\hline & $\begin{array}{l}\text { Agus Priyanto', Eko Priyo Purnomo }{ }^{1,2} \text {, Mochammad Iqbal } \\
\text { Fadhlurrohman }^{1} \text {, Herry Fahamsyah", Etika Khairina }\end{array}$ \\
\hline
\end{tabular}


(1 Departement of Government Affairs and Administration, Universitas Muhammadiyah Yogyakarta, Indonesia)

(2 Jusuf Kalla School of Government, Universitas Muhammadiyah Yogyakarta, Indonesia)

Model Implementation Trap of Policy New Student Acceptance Zoning System in Makassar City

91 - 106 Nuryanti Mustari' ${ }^{1}$, Rudi Hardi ${ }^{1}$, Amir Muhiddin ${ }^{1}$

( ${ }^{1}$ Department of Government Studies, Faculty of Social and Political Sciences, Universitas Muhammadiyah Makassar, Indonesia)

Collaborative Urban Governance Model in Environmental Management of Industrial Area

Tri Sulistyaningsih"1, Saiman', Nofianda Fatimah Azzahra1, Nanda

$107-126$ Adityawan'2, Mohammad Jafar Loilatu ${ }^{3}$

( ${ }^{1}$ Department of Government Studies, Universitas Muhammadiyah Malang Indonesia) (2 Civil Engineering, Sepuluh Nopember Institute of Technology, Surabaya, Indonesia) ( ${ }^{3}$ Government Affairs and Administration, Universitas Muhammadiyah Yogyakarta, Indonesia)

Towards an Integration of Immigration and Customs Agency in Indonesia: A Step-by-Step Process

\section{7 - $144 \quad$ Ridwan Arifin' ${ }^{1}$, Intan Nurkumalawati ${ }^{1}$}

(1 Diploma Program of Immigration Administration, Polytechnic of Immigration, Indonesia) 


\title{
Urban Resilience Strategy in the Climate Change Governance in Makassar City, Indonesia
}

\author{
Ihyani Malik ${ }^{1}$, Andi Luhur Prianto ${ }^{2 *}$, Abdillah Abdillah ${ }^{2}$, Zaldi Rusnaedy ${ }^{3}$, Andi \\ Annisa Amalia ${ }^{4}$
}

\author{
${ }^{1}$ Department of Public Administration, Universitas Muhammadiyah Makassar, Indonesia \\ ${ }^{2}$ Department of Government Studies, Universitas Muhammadiyah Makassar, Indonesia \\ ${ }^{3}$ Department of Government Studies, Universitas Pancasakti Makassar, Indonesia \\ ${ }^{4}$ Department of Architecture, Faculty of Engineering, Universitas Muhammadiyah Makassar, Indonesia
}

*Email Correspondence: luhur@unismuh.ac.id

\begin{abstract}
Urban resilience strategies need to be encouraged to support a broader, planned and integrated development process. Therefore, this paper aims to look at the actualization conditions of urban policies in climate change governance in Makassar City, Indonesia. The research method used is an explorative-qualitative method with a narrative-phenomenological approach where the data sources are primary and secondary data. Data collection through field studies and document studies. The data analysis used is an interactive model. City strategy resilience development model in climate change governance in Makassar City. The results showed that for the first time, the actual condition of Makassar City was under threat of climate change, both biophysically and socio-economically. Second, multilevel governance (MLG) as an ideal model in developing urban resilience, where the principle used is collaborative impact governance, namely building collaboration in policy making to tackle climate change. Third, decentralization as a strategy for implementing resilience, such as national conservation, which begins with the reservation of parks and protected areas. The dominant natural character is controlled under the control of the local government. The number and extent of protected areas are indicators of conservation-based programs implemented by the Makassar City Government.
\end{abstract}

Keywords: Urban resilience; climate change governance; decentralization

\begin{abstract}
ABSTRAK
Strategi ketahanan perkotaan perlu didorong untuk mendukung proses pembangunan yang lebih luas, terencana dan terintegrasi. Oleh karena itu, tulisan ini bertujuan untuk mengetahui kondisi aktual strategi ketahanan perkotaan dalam tata kelola perubahan iklim di kota Makassar, Indonesia. Metode penelitian yang digunakan adalah metode eksploratif-kualitatif dengan pendekatan naratiffenomenologi dimana sumber datanya adalah data primer dan sekunder. Pengumpulan data melalui studi lapangan dan studi dokumen. Analisis data yang digunakan adalah model interaktif. Model pengembangan kapasitas strategi ketahanan kota dalam tata kelola perubahan iklim di Kota Makassar. Hasil penelitian menunjukkan bahwa pertama, kondisi aktual Kota Makassar dalam ancaman perubahan iklim baik secara biofisik maupun sosial ekonomi. Kedua, multilevel governance (MLG) sebagai model ideal dalam pengembangan kapasitas ketahanan kota, di mana prinsip yang digunakan adalah tata kelola kolaboratif yaitu membangun kolaborasi dalam pembuatan kebijakan untuk menanggulangi dampak perubahan iklim. Ketiga, desentralisasi sebagai strategi penerapan kapasitas ketahanan, seperti adanya gerakan konservasi modern yang dimulai dengan pembentukan taman nasional dan kawasan lindung. Karakter alami yang dominan ditempatkan di bawah kendali
\end{abstract}

Citation : Malik, I., Prianto, A. L., Abdillah, Rusnaedy, Z., \& Amalia, A. A. (2021). Urban Resilience Strategy in the Climate Change Governance in Makassar City, Indonesia. Journal of Government and Civil Society, 5(1), 31-50. 
pemerintah daerah. Jumlah dan luas kawasan lindung merupakan indikator keberhasilan program berbasis konservasi yang dilaksanakan oleh Pemerintah Kota Makassar.

Kata Kunci: Kota tangguh; tata kelola perubahan iklim; desentralisasi

\section{INTRODUCTION}

Indonesia's development continues, and the capacity to develop urban resilience at the local government level is limited. Most development interventions are not designed for environmental change but require people to adapt to development. (McCarthy \& Zen2010). Adaptation of cities needs to be improved by identifying development needs and allocating resources to increase adaptive governance capabilities to support a broader comprehensive development process. There is an urgent need to develop urban adaptive capacity for government programs or policies that are vulnerable to climate change to succeed.

The findings of Aylett (2015) show that local governments' ability to mainstream climate change into cities is very low. This is in line with the findings of Cahyadi et al. (2010). As far as Semarang City is concerned, although the Regional Development Planning Agency has coordinated it, it has not fully understood the implementation of the climate change plan in all existing Local Government Agencies. On the other hand, the impacts of climate change occur in several sectors. This situation requires the development of the adaptive capacity to accelerate the implementation of climate change adaptation programs, an integral part of national and regional development policies. This study uses a multi-level governance model and a decentralization strategy

Major cities in Indonesia, including Makassar have realized the impact of climate change. Although this level of awareness has not been translated into proportional institutional commitment (Taylor, 2013; Faisah \& Prianto, 2015), from an institutional perspective, the Civil Society Coalition to Save Indonesian Forests and the Global Climate (2015) notes the readiness of local governments that cannot yet immediately respond to rapid institutional changes at the central level. The strategy to carry out adaptive capacity development is very important in the Makassar city government by looking at its feasibility in strategic areas that are the priority in the Revision of the Makassar City Medium-Term Development Plan (Regional Medium-Term Development Plans) 2019-2020.

This is to understand the actual conditions regarding the City's resilience capacity at the level of climate change governance in Makassar City. Then some questions are formulated: What is the ideal model for city resilience capacity development, and what is the strategy for implementing the urban resilience capacity development model on climate change governance in Makassar City. 


\section{RESEARCH METHOD}

The research was conducted with a phenomenological narrative approach. Data were collected through literature study and empirical observations. Documentation studies were carried out regarding historical data on the actual condition of Makassar City in terms of climate change and governance in the last two years, 2018 and 2019, which were obtained from the Makassar City Central Statistics Agency in 2020 as well as previous research results.

Data analysis techniques are explorative-qualitative, by analyzing multi-level models of governance and decentralization strategies. The qualitative analysis carried out was supported by quantitative data. In particular, the development of climate change conditions in the city of Makassar in the last two years.

\section{RESULTS, DISCUSSION, AND ANALYSIS Existing Condition of Urban Resilience Capacity in Makassar City}

Based on geographic conditions, the coastal city of Makassar in South Sulawesi Province is sensitive to various threats to climate change. According to the climate change model prepared by the Australian Commonwealth of Australia's Scientific and Industrial Research Organization (CSIRO) in 2012, the level of rainfall in Makassar will remain constant. However, rainfall will be concentrated in a relatively short time. In other words, the dry season will be longer, but the average rainfall pattern is not expected to change. The increase in temperature will simultaneously affect the rate of evaporation and sealevel rise. Tidal floods and storm surges pose a threat to coastal communities and intrusion of seawater into coastal aquifers.

The Makassar city government is increasingly aware of the current scope of climate change and its estimated impact. There are many ways to define vulnerability, such as from a climate change perspective, vulnerability is "the extent to which a system is vulnerable or unable to cope with the adverse effects of climate change, including climate variability and extreme weather conditions." To understand vulnerability, it is important to know its three main components: exposure, sensitivity, and adaptability (Taylor, 2013). 
Table 1. Different Indicators Can be Used to Show Levels of Exposure, Sensitivity, and Adaptive Capacity

\begin{tabular}{|c|c|c|}
\hline Exposure & Sensitivity & Adaptation Capacity \\
\hline $\begin{array}{l}\text { Whether or not an area is } \\
\text { exposed to: } \\
\text { - } \quad \text { Flood } \\
\text { - } \quad \text { Drought } \\
\text { - } \quad \text { Sea level rise } \\
\text { - } \quad \text { Temperature rise }\end{array}$ & $\begin{array}{l}\text { Is the area sensitive or not: } \\
\text { - } \quad \text { Located near a flooded } \\
\text { river or canal } \\
\text { - } \quad \text { Have a high poverty } \\
\text { rate } \\
\text { - } \quad \text { Located along the beach } \\
\text { - } \quad \text { Has a low level of } \\
\quad \text { educational attainment } \\
\text { - Often experiences } \\
\quad \text { flooding }\end{array}$ & $\begin{array}{l}\text { Does an area have or does } \\
\text { not have: } \\
\text { - } \quad \text { High quality public } \\
\text { services, such as: clean } \\
\text { water and electricity } \\
\text { - The existence of } \\
\text { community } \\
\text { organizations } \\
\text { - Expenditures for the } \\
\text { public interest of good } \\
\text { quality }\end{array}$ \\
\hline
\end{tabular}

Source: Taylor, 2013

In conducting a vulnerability assessment, the following formula can be used, which is described in terms of three components. According to the United Nation formula:

$$
\text { Vulnerability }=(\text { Exposure } x \text { Sensitivity })-\text { Adaptive Capacity }
$$

Exposure indicates trends in future climate change and associated potential threats based on climate change models and, in some cases, recorded meteorological patterns, where sensitivity indicates which urban systems which societies are in and which areas are more adversely affected by climate hazards certain.

Based on current climate impacts and forecasts, the two most relevant impact scenarios for Makassar City are sea-level rise (including heavy rains, tidal flooding, rising salt in coastal aquifers) and flooding (including major floods and flash floods). Adaptation refers to the individual or collective actions taken by families, communities, organizations, or institutions to minimize the potential impacts of the threat of climate change.

\section{Climate Trends in Makassar City}

Based on current climate impacts and forecasts, the two most relevant impact scenarios for Makassar City are sea-level rise (including heavy rains, tidal flooding, rising salt in coastal aquifers) and flooding (including major floods and flash floods). Adaptation refers to the individual or collective actions taken by families, communities, organizations, or institutions to minimize the potential impacts of the threat of climate change. 
Table 2. Observations of Climate Elements by Moon in Makassar City, 2019

\begin{tabular}{|c|c|c|c|c|c|c|}
\hline \multirow{2}{*}{$\begin{array}{l}\text { Bulan } \\
\text { Month }\end{array}$} & \multicolumn{3}{|c|}{ Suhu/Temperature $\left({ }^{\circ} \mathrm{C}\right)$} & \multicolumn{3}{|c|}{ Kelembaban/Humidity (\%) } \\
\hline & Minimum & $\begin{array}{l}\text { Rata-rata } \\
\text { Average }\end{array}$ & $\begin{array}{c}\text { Maksimum } \\
\text { Maximum }\end{array}$ & Minimum & $\begin{array}{l}\text { Rata-rata } \\
\text { Average }\end{array}$ & $\begin{array}{l}\text { Maksimum } \\
\text { Maximum }\end{array}$ \\
\hline (1) & (2) & (3) & (4) & (5) & (6) & (7) \\
\hline Januari/January & 27.4 & 27.5 & 27.6 & 83 & 85 & 86 \\
\hline Februari/February & 26.8 & 27.4 & 27.9 & 80 & 83 & 86 \\
\hline Maret/March & 27.3 & 27.6 & 27.8 & 82 & 84 & 85 \\
\hline April/April & 28.4 & 28.5 & 28.5 & 80 & 80 & 80 \\
\hline Mei/May & 28.7 & 28.8 & 28.8 & 76 & 78 & 80 \\
\hline Juni/June & 27.7 & 27.8 & 27.8 & 77 & 80 & 82 \\
\hline Juli/July & 27.3 & 27.5 & 27.6 & 71 & 75 & 78 \\
\hline Agustus/August & 27.5 & 27.8 & 28.1 & 68 & 69 & 70 \\
\hline September/September & 28.0 & 28.2 & 28.3 & 73 & 76 & 78 \\
\hline Oktober/October & 29.2 & 29.3 & 29.4 & 68 & 70 & 72 \\
\hline November/November & 29.4 & 29.1 & 29.4 & 74 & 77 & 80 \\
\hline Desember/December & 27.4 & 27.4 & 27.4 & 85 & 85 & 85 \\
\hline
\end{tabular}

Source: Makassar in Figures, BPS (2020)

Makassar has a warm and tropical climate with a difference in the rainy season (November-May) and the dry season (June-October) and is characterized by high humidity, and an average temperature of around $27.8^{\circ} \mathrm{C}$. There is very little change in temperature throughout the year, ranging from $26.8^{\circ} \mathrm{C}$ for the minimum temperature and $29.4^{\circ} \mathrm{C}$ for the maximum temperature. Rainfall in January is $642 \mathrm{~mm}$, and December rainfall is in the range of $281 \mathrm{~mm}$; this figure has fluctuated over the last twenty years, indicating a slight increase in annual rainfall during this period. According to the Meteorology and Climatology Agency (BMKG), during the El Nino year, the rainy season in Makassar is generally delayed by about 10 to 30 days. Meanwhile, the dry season rainfall decreased by between $51-80 \%$. Historical records show that El Nino occurs every 3 to 7 years and often alternates with La Niña Events (CSIRO, 2012). Estimates from the IPCC show that the sea level rise in the 20th century was around $0.17 \mathrm{~ms}$. 


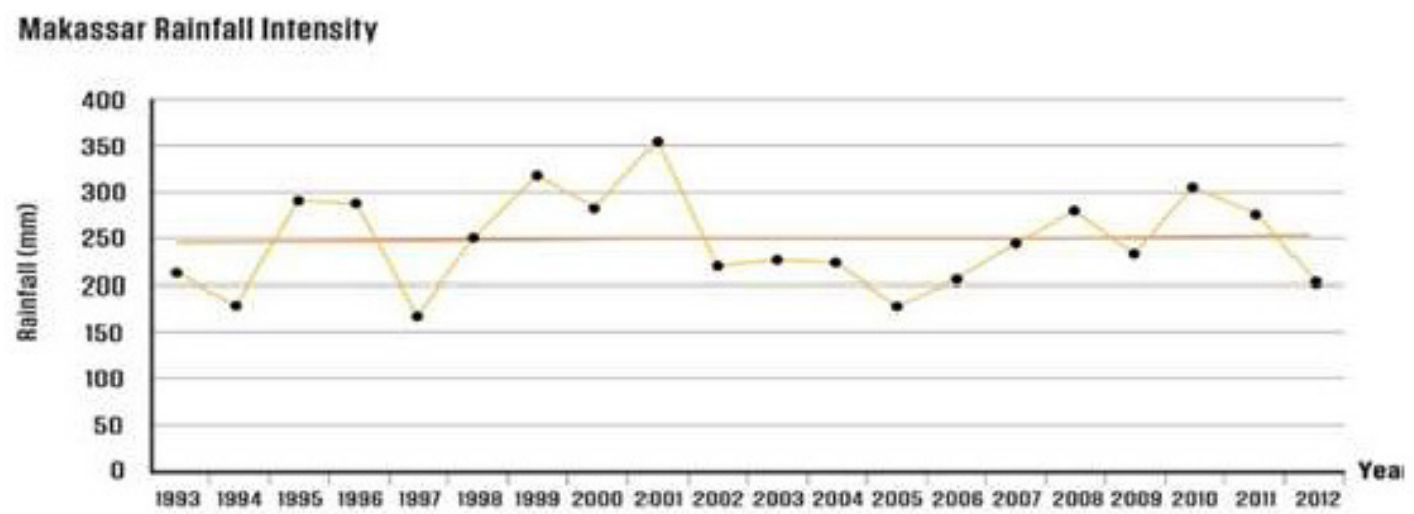

Figure 1. Rainfall in Makassar City Fluctuates with a constant average Source: Maritime Meteorology Paotere Station, 2013

The annual rainfall in Makassar is estimated to increase only slightly, but the rain's intensity will be heavier during the shorter rainy season. Most models project the rainy season's onset to remain unchanged but will reverse 12 days earlier, indicating the concentration of rainfall intensity during the rainy season. In the dry season, the average rainfall decreases by about $36 \%$. In the dry season, the average rainfall decreases by about $36 \%$.

This trend is projected to continue (Maritime Meteorological Station, Paotore, 2013). From 1993 to 2002, sea-level rise in the Makassar Strait increased by $7.5 \mathrm{~cm}$. Based on simulations, it is estimated that sea-level rise in Makassar will reach $88.16 \mathrm{~m}$ in 2025, $1.14 \mathrm{~m}$ in 2050, and $1.44 \mathrm{~m}$ in 2100 (BPPT, 2008). Strong winds along the coast can reach $50-60 \mathrm{~km} / \mathrm{hr}$.

The next most serious climate threat is strong winds. Between 2003 and 2012, 21 reports of strong winds causing 180 deaths and damage to 384 homes. Strong winds have affected coastal communities, especially those living in houses made of poor-quality materials, most of which are considered vulnerable. Other threats recorded were drought, fire, disease outbreaks, and accidents related to industrial activities. Although climate threats are not new to Makassar City, the increase in intensity and unexpected events (such as the unexpected floods earlier this year) remind Makassar City to understand and improve. Overcoming vulnerability, the severity of the climate threat in Makassar City (Prianto, 2019).

The rainy season is shorter but more intense: higher rainfall causes flooding. The most open city areas are the three rivers that flow along with the city, namely the Jeneberang River, the Tallo River, and the Maros River. Currently, it is a sub-urban community and a community with a poor drainage system or not connected to the existing drainage network, especially in empty areas. The worst affected areas are: Tamalanrea, Panakkukang, Rappocini and Manggala. 
Increasing temperatures and increasing drought increasing temperatures will affect areas with bad wind direction, such as densely populated areas in the center of cities. Sea level rise: The area most vulnerable to sea-level rise are the coastal lowlands and offshore island communities. This area includes Tallo, Biringkanaya, Mariso, Tamalanrea and Wajo. Strong winds and coastal erosion: The city's southern and western areas are particularly vulnerable to strong winds and large waves. The sub-regions are: Tamalate, Manggala, Panakukukang, Tallo, and Biringkanaya. Strong winds and coastal erosion can damage homes, infrastructure, and property.

Although the climate threats mentioned above may have a greater impact in these areas than other areas of the city, certain communities and urban systems are also more vulnerable to these threats than in other areas. For example, where the urban poor in coastal areas are located, they are more vulnerable to strong winds, sea-level rise, and coastal erosion. The next section will explore the scope of this influence, but here is a list of urban systems and people exposed to urban climate threats:

An open urban system: drainage system, clean water distribution, coastal barrier, roads, major infrastructure (Rusnaedy \& Haris, 2021). Exposure to urban population: poor urban communities in coastal areas, people were living in new residential areas, commercial and industrial activities in coastal areas, and commercial activities that rely on open infrastructure. Makassar City concentrates its goods, services and services, population, infrastructure, and economic activities in a relatively dense urban area (76.8 people/ha) to be increasingly sensitive to disturbances due to climatic threats. The next section on climate change sensitivity will begin to understand how systems will be affected by climate threats and study what factors make them vulnerable.

\section{Climate Change Sensitivity}

Sensitivity is defined as the degree to which a system is affected by climate change's biophysical effects. It considers the socio-economic background of the system being assessed and other non-climatic stressors that can affect the city's vulnerability, such as the economy, development planning, administrative management, and ecosystem management.

The exposure analysis determined that the greatest climate threat in Makassar was the sea-level rise, increased rainfall/flooding, strong winds and waves, high temperatures, and drought. These hazards will affect different parts of the city in different ways, so understanding the primary and secondary consequences is important to find ways to reduce vulnerability. The table below lists the various effects of each climate hazard. 
Table 3. Primary and Secondary Impacts of Four Climate Change Threats Faced in Makassar City

\begin{tabular}{|c|c|c|c|}
\hline $\begin{array}{l}\text { Threats of } \\
\text { Climate } \\
\text { Change }\end{array}$ & $\begin{array}{l}\text { Biophysical } \\
\text { Impact }\end{array}$ & Primary Impact & Secondary Impact \\
\hline Sea level rise & $\begin{array}{l}\text { Puddle in the } \\
\text { coastal area }\end{array}$ & $\begin{array}{l}\text { Damage to coastal ecosystems } \\
\text { causes migration and economic } \\
\text { problems for fishing communities } \\
\text { Seawater intrusion in water } \\
\text { sources } \\
\text { coastal areas reduce the } \\
\text { availability of clean water for the } \\
\text { poor in coastal areas } \\
\text { Slow loss of coastal land due to } \\
\text { abrasion on the islands and } \\
\text { lowlands in the coastal area. } \\
\text { Damage to physical infrastructure } \\
\text { built by coastal communities } \\
\text { Impoverishment and forced } \\
\text { displacement of affected coastal } \\
\text { communities }\end{array}$ & $\begin{array}{l}\text { Disruption of } \\
\text { economic activities, } \\
\text { settlements, ports } \\
\text { and tourism } \\
\text { activities - economic } \\
\text { losses } \\
\text { The chaos of the } \\
\text { road and } \\
\text { transportation } \\
\text { system resulting in } \\
\text { economic losses }\end{array}$ \\
\hline $\begin{array}{l}\text { Increased } \\
\text { rainfall / } \\
\text { flooding }\end{array}$ & $\begin{array}{l}\text { Septic tank } \\
\text { and well } \\
\text { overflowed. } \\
\text { Stagnant } \\
\text { water in } \\
\text { areas without } \\
\text { drainage } \\
\text { Clean water } \\
\text { is } \\
\text { contaminated }\end{array}$ & $\begin{array}{l}\text { Diseases caused by water and } \\
\text { carried by mosquitoes } \\
\text { Damage to settlements and } \\
\text { infrastructure, especially in } \\
\text { lowland areas } \\
\text { Contamination } \\
\text { wells with e-coli bacteria from } \\
\text { around them } \\
\text { Damage to agricultural produce in } \\
\text { rural and suburban areas }\end{array}$ & $\begin{array}{l}\text { Decreasing profits } \\
\text { from agricultural } \\
\text { production } \\
\text { Decreasing local } \\
\text { food supply, } \\
\text { increasing prices } \\
\text { which have an } \\
\text { impact on poor } \\
\text { households } \\
\text { Decreasing } \\
\text { availability of clean } \\
\text { water, increasing } \\
\text { prices, has an } \\
\text { impact on poor } \\
\text { households } \\
\text { Economic } \\
\text { disruption is caused } \\
\text { by partial } \\
\text { disturbances in } \\
\text { urban movement }\end{array}$ \\
\hline
\end{tabular}




\begin{tabular}{|c|c|c|c|}
\hline $\begin{array}{l}\text { Gale and } \\
\text { waves }\end{array}$ & $\begin{array}{l}\text { Damage to } \\
\text { local } \\
\text { buildings } \\
\text { and } \\
\text { infrastructure }\end{array}$ & $\begin{array}{l}\text { Damage to business and } \\
\text { household activities caused high } \\
\text { costs and economic losses. } \\
\text { Impoverishment of people in } \\
\text { coastal areas who experience loss } \\
\text { of assets and houses. } \\
\text { The displacement of coastal } \\
\text { communities has resulted in } \\
\text { migration } \\
\text { Reduced catch for small ships }\end{array}$ & $\begin{array}{l}\text { The fishing industry } \\
\text { is impacted by the } \\
\text { limited catch of } \\
\text { marine products. } \\
\text { The decline in } \\
\text { seafood exports has } \\
\text { resulted in a } \\
\text { decrease in people's } \\
\text { income }\end{array}$ \\
\hline \multirow[t]{2}{*}{$\begin{array}{l}\text { Heat and } \\
\text { dryness }\end{array}$} & \multirow[t]{2}{*}{$\begin{array}{l}\text { Damage to } \\
\text { agricultural } \\
\text { produce }\end{array}$} & $\begin{array}{l}\text { Continued migration of workers } \\
\text { from rural to urban areas. } \\
\text { Hot air attacks affect children and } \\
\text { the elderly, increasing the risk of } \\
\text { death } \\
\text { The local food supply is } \\
\text { decreasing, rising prices have an } \\
\text { impact on poor households }\end{array}$ & $\begin{array}{l}\text { The increase in } \\
\text { energy } \\
\text { consumption for air } \\
\text { conditioning or } \\
\text { pump water has an } \\
\text { impact on the } \\
\text { income of the poor }\end{array}$ \\
\hline & & $\begin{array}{l}\text { The availability of clean water } \\
\text { decreases, prices go up, impacting } \\
\text { poor households }\end{array}$ & $\begin{array}{l}\text { New migrant } \\
\text { residents from rural } \\
\text { to urban living in } \\
\text { locations that are at } \\
\text { risk, exacerbating } \\
\text { the vulnerability of } \\
\text { the city }\end{array}$ \\
\hline
\end{tabular}

\section{Sensitivity and Vision of Makassar City}

Climate models predict that climate change will increase rainfall intensity and significantly increase sea levels. Simultaneously, the city's situation experienced difficulties due to prolonged flooding, damage from strong winds, and damage to beaches. However, even though they recognize the importance of climate change on the future of cities, there is still a mismatch between the current vision of city governments on "world cities" and the vulnerability and disasters associated with climate threats.

The city government has taken the right steps to increase funding to support environmental policies and improve water management. This shows that the issue of climate change is a top priority. The government has made great efforts to allocate more funds for environmental protection, conservation, and the creation of green open spaces. In the last REGIONAL MEDIUM-TERM DEVELOPMENT PLANS, the spatial and environmental development budget increased from $21 \%$ to $37 \%$. Also, support is needed 
to improve the management and distribution of clean water. The budget allocation for improved management and clean water allocation has increased by $85 \%$ compared to the two previous regional sanitation management plans. The budget for clean water projects has also increased from Rp 8 billion to Rp 33 billion.

However, in the face of rapid urbanization in the suburbs, there is no clear planning direction, such as an overall drainage plan or an increase in per capita spending on the city's outskirts. Each institution must be marked but not displayed as part of the REGIONAL MEDIUM-TERM DEVELOPMENT PLANS. Also, there are no plans to manage metropolitan issues related to environmental management, such as watershed (DAS) management, linkages between roads and metropolitan areas, and no vision for a "world city," which focuses on cities rather than public and private investment. In most areas.

As a result, the current vision plan for Makassar does not match the resources needed to transfer development trends to the downtown area. Not following the reality of development trends and not following the needs and services of facilities and infrastructure. This trend could further increase Makassar's vulnerability to future climate threats. Those who suffer the most are those who live in large areas on the outskirts of cities, without government investment, and of course, the poor.

The following subsections provide examples of urban resilience. This example shows what actions are being taken to reduce vulnerability to climate threats and increase urban resilience. The examples are grouped into various levels according to how they work. 
Table 4. Actions to Reduce Vulnerability to The Threat of Climate Change and Increase City Resilience

\begin{tabular}{|c|c|c|}
\hline $\begin{array}{c}\text { Individual Capacity Level } \\
\text { (HR Development) }\end{array}$ & $\begin{array}{l}\text { Organizational Capacity } \\
\text { Level (Organizational } \\
\text { Strengthening) }\end{array}$ & $\begin{array}{c}\text { Capacity System } \\
\text { (Institutional Reform) }\end{array}$ \\
\hline $\begin{array}{l}\text { Preventing flooding and } \\
\text { sea-level rise at the } \\
\text { household level: In the } \\
\text { informal settlement of } \\
\text { Tanjung Bangka, poor } \\
\text { families build concrete paths } \\
\text { (about } 20-30 \mathrm{~cm} \text { high) at the } \\
\text { entrance to their houses to } \\
\text { protect them. Prevent the } \\
\text { house from being damaged } \\
\text { by low-altitude flooding. } \\
\text { Residents say that floods } \\
\text { occur every year. Such } \\
\text { embankments cannot be } \\
\text { used as a long-term solution } \\
\text { but are necessary to prevent } \\
\text { frequent flooding. }\end{array}$ & $\begin{array}{l}\text { Community-based } \\
\text { mangrove restoration: To } \\
\text { protect their homes and } \\
\text { livelihoods from strong } \\
\text { winds and waves, the } \\
\text { people of Lanta State and } \\
\text { local NGOs have } \\
\text { implemented a mangrove } \\
\text { forest project. }\end{array}$ & $\begin{array}{l}\text { Poor Social Welfare } \\
\text { Program: In Indonesia, the } \\
\text { government provides social } \\
\text { welfare policies for the poor, } \\
\text { which can act as a social } \\
\text { safety net in the face of } \\
\text { climate disasters or climate } \\
\text { hazards. The following list } \\
\text { outlines various social } \\
\text { welfare policies designed to } \\
\text { help the poor: }\end{array}$ \\
\hline $\begin{array}{l}\text { Reinforcing building } \\
\text { materials to protect } \\
\text { buildings from strong } \\
\text { winds, in the informal } \\
\text { settlements of Tallo along } \\
\text { the coastline, residents have } \\
\text { developed strategies to } \\
\text { protect houses from strong } \\
\text { winds and waves. Roof and } \\
\text { pillar support use ropes and } \\
\text { cables to provide additional } \\
\text { reinforcement to structure of } \\
\text { the building. Residents said } \\
\text { that continued damage to } \\
\text { homes was common in } \\
\text { January and February. } \\
\text { Therefore, it is necessary to } \\
\text { reinforce the roof and walls } \\
\text { to strengthen the structure. }\end{array}$ & $\begin{array}{l}\text { In recent years, Bachtiar has } \\
\text { made ambitious efforts for } \\
\text { residents to protect his } \\
\text { community from strong } \\
\text { winds by restoring coastal } \\
\text { mangrove forests. This sport } \\
\text { protects homes and other } \\
\text { tangible assets and attracts } \\
\text { the attention of crabs, fish, } \\
\text { and birds that previously } \\
\text { disappeared due to the } \\
\text { destruction of natural } \\
\text { mangroves. This movement } \\
\text { can create small crab } \\
\text { processing companies and } \\
\text { generate income for the } \\
\text { community. } \\
\text { Fish traders and fishermen } \\
\text { use SMS to exchange }\end{array}$ & $\begin{array}{l}\text { RASKIN (stands for Rice for } \\
\text { Poor Families). Raskin is a } \\
\text { national program that } \\
\text { distributes subsidized rice } \\
\text { to the poorest people. This } \\
\text { program was started in } 1998 \\
\text { following the economic } \\
\text { crisis and provided } 20 \mathrm{~kg} \text { of } \\
\text { rice to each poor household } \\
\text { every month. }\end{array}$ \\
\hline
\end{tabular}




\begin{tabular}{|c|c|c|}
\hline & $\begin{array}{l}\text { information on prices and } \\
\text { weather conditions; } \\
\text { fishermen from Barrang } \\
\text { Caddi use SMS to exchange } \\
\text { information about weather } \\
\text { conditions and market } \\
\text { prices for fish. Fishermen at } \\
\text { Tanjung Bunga report that } \\
\text { weather conditions at sea, } \\
\text { especially wind patterns, } \\
\text { have increased } \\
\text { unexpectedly, which means } \\
\text { there is a risk to consider } \\
\text { using small boats. SMS } \\
\text { services to share } \\
\text { information about fish } \\
\text { prices and weather } \\
\text { conditions allow fishermen } \\
\text { to decide to stay at home or } \\
\text { do other work to improve } \\
\text { the family economy. }\end{array}$ & \\
\hline $\begin{array}{l}\text { Collecting rainwater: } \\
\text { Collecting rainwater by } \\
\text { pouring rainwater from the } \\
\text { roof into a plastic container } \\
\text { and storing it. In Makassar, } \\
\text { from the stilt house in Tallo } \\
\text { to the Panambungan and } \\
\text { Untia communities, similar } \\
\text { efforts are seen at all society } \\
\text { levels. Given that there are } \\
\text { still some areas in the city } \\
\text { that do not have access to } \\
\text { clean water provided by } \\
\text { PDAM, it is necessary to } \\
\text { have an adaptation strategy } \\
\text { to ensure that families have } \\
\text { access to clean water. } \\
\text { According to the climate } \\
\text { model created by CSIRO, } \\
\text { higher temperatures will }\end{array}$ & $\begin{array}{l}\text { Community development } \\
\text { planning and budgeting: } \\
\text { Two policies initiated by the } \\
\text { government, Development } \\
\text { Planning Forum, assist the } \\
\text { participatory development } \\
\text { planning and budgeting } \\
\text { process at the sub-district } \\
\text { level. Development } \\
\text { Planning Forum is a local } \\
\text { government program, while } \\
\text { PNPM is a loan program } \\
\text { from the central } \\
\text { government. Both provide } \\
\text { opportunities for residents } \\
\text { to discuss and propose } \\
\text { small infrastructure projects } \\
\text { that meet basic community } \\
\text { needs. On Lae-Lae Island, } \\
\text { communities use }\end{array}$ & $\begin{array}{l}\text { RASKIN (stands for Rice for } \\
\text { Poor Families). Raskin is a } \\
\text { national program that } \\
\text { distributes subsidized rice } \\
\text { to the poorest people. This } \\
\text { program was started in } 1998 \\
\text { following the economic } \\
\text { crisis and provided } 20 \mathrm{~kg} \text { of } \\
\text { rice to each poor household } \\
\text { every month. }\end{array}$ \\
\hline
\end{tabular}




\begin{tabular}{ll}
\hline $\begin{array}{l}\text { increase evaporation, while } \\
\text { a shorter rainy season will }\end{array}$ & $\begin{array}{l}\text { Development Planning } \\
\text { impact the city's water }\end{array}$ \\
$\begin{array}{l}\text { Fupply. The poor and } \\
\text { breakwaters, sea dikes, and } \\
\text { disadvantaged groups will }\end{array}$ & $\begin{array}{l}\text { reduce wear and sensitivity } \\
\text { from rising sea levels, strong } \\
\text { be greatly affected by this. }\end{array}$ \\
& winds, and heavy rains.
\end{tabular}

\section{Multilevel Governance (MLG) Model in Resilience Capacity Development}

The Multilevel Governmental Model (MLG) is a governance approach introduced by the European Union government system in the early 1990s (Janicke, 2017: 110; Hooghe \& Marks, 2001). An important keyword of MLG theory and approach is collaboration. Bache and Flinders (2004) use the MLG concept to understand the dynamic relationship between different government levels and between governments (Kern \& Bulkeley, 2009). Although the concept of multilevel governance was first proposed around the European Union, many of its forms have already been applied to other areas of research, such as federal states in comparative politics. McCormick believes that "multilevel governance is a cousin of the two old concepts of federalism and alliance" (Jänicke, Schreurs, \& Töpfer, 2015).MLG can also be understood as a multi-central government system, namely a government system where each part does not see it as a challenge but as a support for innovation in policy tools, learning processes, and technology combinations (Sovacool, 2011).

The MLG research perspective has emerged as a 'useful middle-class framework for analyzing socio-technical transitions to sustainability. A multilevel climate governance system understood in 'socio-technical terms refers to a specific group of technologies low-carbon technologies - and the policies and institutions that support them. This is a necessary specification regarding this particular technology group (Janicke, 2017; Geels, 2011). In global climate governance, the MLG concept is indispensable. This can be explained as follows: 
Table 5. Global Climate Governance as a City Resilience System

Multi-level Climate Governance (MLG) as a System of City Resilience
1. Sustainable development and climate protection must be a global approach. Global
governance, however, requires an intermediate level of the global political system.
2. The role of each level - from global to local - is very specific. It has its responsibilities,
challenges, and opportunities. Moreover, it has specific horizontal dynamics: peer-
to-peer learning, competition, and cooperation. Horizontal networks of cities and
provinces/states have become global players in climate governance.
3. Vertical interactions offer additional potential: improved best practice through
higher-level policies and lower-level policy support. Vertical and horizontal MLG
interactions have been at the center of high-speed interactive learning and the spread
of technical and political innovation. It is essentially a multi-impulse system for
climate-related innovations.
4. Multi-level climate governance is also usually understood as multi-sectoral or multi-
stakeholder governance, making it a model that can address all scales and all
relevant interest groups in global climate governance.

Source: Janicke, 2017: 110-111

There are two types of MLG (Hooghe \& Marks, 2002). The first type is a hierarchical approach, focusing on how powers and powers are divided between different government levels. The second type is a multi-center model in which several overlapping and interconnected areas of horizontal authority participate in adjusting a particular problem. As an environmental management system, MLG is very important for several reasons, including: (1) It is comprehensive from global to local; (2) The role of each level - from global to local - is very specific; (3) Vertical interactions provide additional potential for MLG as a system; (4) Multi-sectoral, multi-stakeholder (Jänicke, 2017).

Global governance requires national and local governments to be part of the global political system. The roles at each level, from global to local, are very specific. Governments have their responsibilities, challenges, and opportunities and have specific horizontal dynamics: learning, competition, and cooperation between institutions. Horizontal networks of cities and provinces/states have become global players in climate governance. Vertical interactions offer MLG more potential as a system: enhancing best practices through higher-level strategy and lower-level strategy support. MLG's vertical and horizontal interactions have always been at the center of highly interactive learning and the rapid spread of technological and political innovations. This is an innovative multi- 
impulsive system related to climate change. This makes MLG a model that can solve all scale problems in global climate governance and solve the problems of all relevant interest groups. This is illustrated as follows:

Table 6. The Role of Each Actor in The MLG Governance System According to Janicke (2017)

\begin{tabular}{ll}
\hline \multicolumn{1}{c}{ Government Level } & \multicolumn{1}{c}{ Role } \\
\hline Global & International institutions such as the United Nations \\
& Environment Program (UNEP) and the Commission on \\
& Sustainable Development act as institutions that regulate the \\
& global climate policy agenda and then pass it on to member \\
& countries. \\
& Play a role in supranational activities to realize common \\
& interests, and play a role in discussing solutions to common \\
United States & problems in the region. \\
& Has special responsibility in implementing national policies. \\
& This is the level at which most national regulations must be \\
National & implemented \\
Province / Region & Driving environmental friendly technology / lifestyle \\
Public & initiatives / ideas \\
& Members of governance and goals and the foundation of climate \\
knowledge global (for example, IPCC report)
\end{tabular}

A climate vulnerability study in Makassar City from UN-Habitat \& UNDP Indonesia in 2020 shows how sensitive climate change impacts climate change in Makassar city. Makassar is defined based on its geographical location and the various systems, economies, and communities that make it a city. Therefore, it considers the socio-economic context of the system deemed necessary and other non-climatic pressure factors that may affect the vulnerability of cities, such as the economy, development plans, administrative and ecosystem management.

The impact of climate change in Makassar City identifies that the greatest climate threat to Makassar City is sea level rise, increased rainfall/flooding, strong winds, waves, heat, and drought. These hazards will impact different parts of the city and in different ways. Understanding the various consequences, both primary and secondary impacts, is important to find ways to reduce vulnerability to communities. Because it's a Multilevel 
model Governance (MLG) approach as an ideal model in developing cities' resilience capacity, using collaborative principles of governance.

\section{Decentralization as a Strategy for Implementing The Resilience Capacity Development Model for The City of Makassar}

Decentralization can be understood as the transfer of political, financial, and administrative authority from the central government to local governments (Nurmandi, et al., 2015). Many factors support the success of a decentralized system, including: (1) institutions and human resources that are qualified to implement plans in the decentralized system; (2) infrastructure, technology, access to information, human resources, capacity for institutional planning, and the appropriate distribution of benefits from natural resources (Colfer \& Capistrano, 2006).

The concept of decentralization has become a strategy for countries to protect the environment following the spirit of democracy, pluralism, and equal rights and to safeguard the allocation of resources and power at the social level (Agrawal \& Ostrom, 2001). Previous research has shown that decentralization hinders the development of climate change policies because, among other things:(1) Bureaucratic relations between all levels of government in a complex decentralized system and field studies show that this slows down the progress of regional and national climate change policies (Steurer \& Clar, 2014); (2) The politics of climate change will be influenced by the politics of the federal government, therefore, even if the public supports issues like the United States, without support from the federal government and the political parties behind it, climate change will easily fail (Koski \& Siulagi, 2016).

For example, the Double experience is an example of ineffective governance of climate change, leading to its climate policy plans' failure. For more than a decade, the central government has regulated the many roles that local governments must play, such as: (i) appointing and rewarding regional heads, (ii) eliminating sources of revenue at the regional level, and (iii) allocating small budgets for the non-government sector. Produce. This puts the region at the acceptance stage without making a decision. Also, they have established a "patron-customer relationship" between the central government and regional heads and are unable to hold officials accountable (Ampaire et al., 2017).

Indonesia's experience showed that several important issues from the decentralized practice of Indonesia's forest management department. This study found several main problems in various government departments, such as (1) bureaucracy at the center, (2) statutory regulations, (3) local government/community. According to this study, with an understanding of the spirit of autonomy, the implementation of forestry decentralization should not be trapped in the power issue between the center and the regions (Siswanto \& Wardojo, 2006). For example, at the provincial and district levels, the public sector's 
hierarchical status often restricts lower-level civil servants from coordinating or directing the heads of other high-level institutions (McCharty \& Zen, 2009). However, it must be in the spirit of building social welfare for the community and realizing sustainable forest management (Siswanto \& Wardojo, 2006).

In the study of local government system governance, it is believed that these two dimensions can be achieved through the same coordination and unity of vision between the center and the regions (Abdillah, 2020). Administrative boundaries should not be a barrier to forest sector management. On the other hand, the government, the private sector, and the community must work together to get social benefits from these forest products through sustainable programs to build urban resilience due to the impact of climate change in Makassar City. The failure of the forestry decentralization political system in Indonesia can be seen from the sluggishness of the forestry sector bureaucracy, the emergence of conflicts between various parties, such as the complexity of field problems and errors in explaining forest management models, and forest degradation (Siswanto \& Wardojo, 2006). Some of the obstacles of the decentralized political system to the management of the forestry sector in Indonesia can be seen in the following table:

Table 7. Barriers of a Decentralized Political System to The Forestry Sector in Various Countries

\begin{tabular}{|c|c|}
\hline Government Level & Role \\
\hline Global & $\begin{array}{l}\text { International agencies such as the United Nations Environment } \\
\text { Program (UNEP) and the Commission on Sustainable } \\
\text { Development act as bodies that regulate the global climate } \\
\text { policy agenda which is then forwarded to member countries. }\end{array}$ \\
\hline United States & $\begin{array}{l}\text { Play a role in supranational articulation for the common good and } \\
\text { the discussion of solutions to common problems in the region. }\end{array}$ \\
\hline National & Has special responsibility in implementing national policies. \\
\hline Province / Region & $\begin{array}{l}\text { This is the level where most national regulations should be } \\
\text { implemented. }\end{array}$ \\
\hline Public & $\begin{array}{l}\text { Driving environmental friendly technology/ lifestyle } \\
\text { initiatives/ideas. }\end{array}$ \\
\hline Individual & $\begin{array}{l}\text { Members of governance and goals and the foundation of climate } \\
\text { knowledge global (for example, the IPCC report). }\end{array}$ \\
\hline
\end{tabular}

Source: Processed by Researchers from Janicke, 2017: 112-114, 2020 
The political strategy of decentralization as the development of resilience capacity in Makassar City aims at sustainable development based on a green environment to increase the resilience of Makassar City due to the frequent impacts of climate change. The modern conservation movement began with the establishment of national park areas and similar protected areas, in which the prominent natural character is placed under permanent state control. The removal of important natural areas from local control and their designation as state-controlled protected areas is a generally accepted paradigm. The number and extent of protected areas are often the main criteria for the conservation programs' success pursued in Makassar City.

\section{CONCLUSION}

Local governments can reduce vulnerability to climate change by influencing the sensitivity and adaptive capacity of urban communities. This can be done both through physical actions (such as improving natural and artificial systems and climate-resilient infrastructure) and actions of a non-physical nature (such as capacity building and public service administration, supporting local community organizations improving institutional coordination).

Various studies have tried to explain why countries fail to implement climate change mitigation and adaptation plans at the international level. One element of research is the governance aspect, and this aspect shows that the decentralized system tends to hinder the implementation of climate change mitigation and adaptation plans. Model The Multilevel Governance (MLG) Approach as an Ideal Model for City Resilience Capacity Development in Makassar where the principle used is the collaborative principle of governance, namely building stakeholder actor collaboration to build urban resilience due to the dangerous impacts of climate change. For several reasons: at its heart is an international plan, like climate change. For Indonesia itself, climate change becomes important when the Sustainable Development Goals (SDGs) include climate change as one of the SDGs' strategic issues in developing countries in 2015. This legitimizes the issue of climate change as an important agenda in Indonesia's RPJM to Makassar City.

This has been reflected in the governance of climate change in many European states. Decentralization has created other factors which prove to be problematic for the success of climate governance in Indonesia. One example is the implementation of climate policy in North Sumatra. These constraints can be seen from several aspects, including: (1) Although many climate change activities in this area require special funds and are different from other regions, the decentralization system does not support funding that is not following central government policies; (2) Decentralization of electricity creates a more complex situation, making coordination between various powers and centers of power more difficult. This will also affect coordination and consistency of plans; (3) Because the 
characteristics of the division of responsibilities have not been accompanied by technical improvements in local communities' capacity, nor have they been accompanied by a greater distribution of power at the local level. Increase the appropriate technical skills to perform the required tasks, such as recording greenhouse gas emissions. Right. It is hoped that by 2021, Makassar City will apply the same implementation strategy model. So far, climate change mitigation and adaptation strategies have become important strategies to reduce the risk of disasters due to climate change in various vulnerable areas.

\section{REFERENCES}

Abdillah, A., Deliarnoor, N. A., Yuningsih, N. Y., \& Fatmawati, F. (2020). The Position of Auxiliary Organ in Government System of West Java Provincial Government. Journal of Contemporary Governance and Public Policy, 1(2), 67-81. doi:10.46507/jcgpp.v1i2.11. Agrawal, A., \& Ostrom, E. (2001). Collective Action, Property Rights, and Decentralization in Resource Use in India and Nepal. Politics E Society, 29(4), 485-514. doi:10.1177/ 0032329201029004002.

Aylett, Alexander (2015), “Institutionalizing The Urban Governance of Climate Change Adaptation: Results Of An International Survey", dalam Urban Climate Vol. 14 (2015), hal 4-16 https://doi.org/10.1016/j.uclim.2015.06.005

BMG Kota Makassar (2013). Prakiraan Musim Kemarau Tahun 2013 di Indoensia. Dokumen

: Badan Meteorologi dan Geofisika, Makassar.

BPS Kota Makassar. (2020). Kota Makassar Dalam Angka 2020. Dokumen: Badan Pusat Statistik Kota Makassar.

Cahyadi, Rusli (2010),"Adaptasi Pemerintah Daerah Terhadap Dampak Perubahan Iklim : Peluang dan Tantangan", Laporan Penelitian, Bappaeda Kota Semarang.

Carol J. Pierce Colfer dan Doris Capistrano. 2006. Politik Desentralisasi Hutan, Kekuasaan dan Rakyat Pengalaman di berbagai Negara, (Bogor: Center for International Forestry Research (CIFOR)), hal 178-179

Faisah, N. \& Prianto, A.L. (2015) Good Environmental Governance (Studi Kasus Pengelolaan Taman Macan di Kota Makassar), Otoritas (Jurnal Ilmu Pemerintahan). 9 (1): hal. 2841. https://doi.org/10.26618/ojip.v5i2.122

Geels FW. 2011. The multi-level perspective on sustainability transitions: responses to seven criticisms. Environmental Innovation and Societal Transitions 1(1): 24-40. DOI:10.1016/j.eist.2011.02.002.

Hooghe, L., \& Marks, G. N. (2002). Types of Multi-Level Governance. SSRN Electronic Journal, 4-6. doi:10.2139/ssrn.302786.

Jänicke, M. (2017). The Multi-level System of Global Climate Governance - the Model and its Current State. Environmental Policy and Governance, 27(2), 108-121. doi:10.1002/ eet.1747. 
Kern, K., \& Bulkeley, H. (2009). Cities, Europeanization and Multi-level Governance: Governing Climate Change through Transnational Municipal Networks. JCMS: Journal of Common Market Studies, 47(2), 309-332. doi:10.1111/j.1468-5965.2009.00806.x.

Koalisi Masyarakat Sipil untuk Penyelamatan Hutan Indonesia dan Iklim Global, (2015). "Perkuat Agenda Perubahan Iklim dan Komitmen Indonesia Melindungi Hutan", Briefing Paper, Koalisi Masyarakat Sipil untuk Penyelamatan Hutan Indonesia dan Iklim Global.

M. Jänicke, M, M. Schreurs, \& K. Töpfer. 2015. The Potential of Multi-Level Global Climate Governance. IASS POTSDAM, hlm 1-12 https://goo.gl/XLiz8v.

McCarthy, J., \& Zen, Z. (2010). Regulating the Oil Palm Boom: Assessing the Effectiveness of Environmental Governance Approaches to Agro-industrial Pollution in Indonesia. Law $\mathcal{E}$ Policy, Vol. 32 (1) hal.153-179 https:// doi.org/10.1111/j.1467-9930.2009.00312.x

Nurmandi, A., Purnomo, E. P., Prianto, A. L., \& Jaenuri, M. (2015). The current practice of citizen participation in Indonesia netizen and selected cases of local democracy in Indonesia. Citizen Participation, 21.

Prianto, A. L. \& Amalia, A. A. (2019). “Combatting Slums, Suistaining Proverty: Dynamic Urban Governance in Makassar, Indonesia”. Otoritas (Jurnal Ilmu Pemerintahan). 5(2): hal. 174-188. https://doi.org/10.26618/ojip.v9i1.2008

Sovacool, B. K. (2011). An international comparison of four polycentric approaches to climate and energy governance. Energy Policy, 39(6), 3832-3844. doi:10.1016/ j.enpol.2011.04.014.

Steurer, R., \& Clar, C. (2014). Is decentralisation always good for climate change mitigation? How federalism has complicated the greening of building policies in Austria. Policy Sciences, 48(1), 85-107. doi:10.1007/s11077-014-9206-5.

Taylor, J. (2013). Kajian Kerentanan Iklim di Kota Makassar. Makassar: UN-Habitat \& UNDP Indonesia

Siswanto, W., \& Wardojo, W. (2006). Desentralisasi Sektor Kehutanan: Pengalaman Indonesia. Politik Desentralisasi Hutan, Kekuasaan dan Rakyat: Pengalaman di berbagai Negara, 175-185.

Rusnaedy, Z., \& Haris, A. (2021). Advocacy Coalition in The Arrangement of The Coastal Slum Area of Untia in Makassar. Journal of Governance and PublicPolicy, $8(1)$. 